\title{
ЗМІНИ ЦИТОКІНОВОГО ПРОФІЛЮ В ЩУРІВ 3 ПАРОДОНТИТОМ НА ТЛІ ГІПЕР- ТА ГІПОТИРЕОЗУ
}

Вступ. В Україні поширеність захворювань пародонта серед населення віком 35-44 роки становить від 92 до 98 \%. Питання гормональної регуляції запальних реакцій у пародонті й особливості їх розвитку на тлі дисфрункції щитоподібної залози залишаються недостатньо вивченими.

Мета дослідження - вивчити цитокіновий профріль сироватки крові та гомогенату пародонта в щурів з пародонтитом без супутньої патології і на тлі гіпер- та гіпотиреозу.

Методи дослідження. Дослідження виконано на білих щурах-самцях, в яких моделювали пародонтит, пародонтит на тлі гіпертиреозу та пародонтит на тлі гіпотиреозу. В сироватці крові та супернатанті гомогенату пародонта визначали вміст інтерлейкінів (IL) 1及, 4 і 10 методом твердофразового імунофрерментного аналізу з використанням наборів реагентів "RayBio" виробництва "RayBiotech" (США).

Результати й обговорення. Вміст прозапального IL-1 $\beta$ у сироватці крові щурів із змодельованим пародонтитом зріс в 1,6 раза $(p<0,001)$ відносно контрольної групи. У тварин із змодельованим пародонтитом на тлі гіпертиреозу цей показник збільшився у 2,5 раза $(p<0,001)$ щодо контрольної групи. Варто вказати, що концентрація IL-1 $\beta$ у сироватці крові гіпертиреоїдних щурів на 51,5 \% достовірно перевищила величину даного показника за умов пародонтиту без супутньої патології та на 37,7 \% (p<0,001) - при пародонтиті на тлі гіпотиреозу. Вміст протизапального IL-10 зменшився на 51,3 \% ( $p<0,001)$ у сироватці крові тварин із змодельованим пародонтитом відносно контрольної групи. У щурів із змодельованим пародонтитом на тлі гіпертиреозу даний показник знизився на 69,9\% (p<0,001) щодо контрольної групи. При цьому вміст IL-10 у сироватці крові гіпертиреоїдних тварин на 38,1 \% був достовірно меншим від даного показника за умов пародонтиту без супутньої патології та на 19,0 \% $(p<0,05)$ - при пародонтиті на тлі гіпотиреозу.

Висновки. Експериментальний пародонтит супроводжується вираженим підвищенням концентраціі прозапальних цитокінів на тлі зниження концентрації протизапальних цитокінів як у гомогенаті пародонта, так і в сироватці крові, що свідчить про розвиток не лише локальних запальних реакцій, але й системних. Дисбаланс тиреоїдних гормонів впливає на перебіг запалення при експериментальному пародонтиті, особливо виражено - при гіпертиреозі.

КЛЮчОВІ СЛОВА: пародонтит; цитокіни; гіпотиреоз; гіпертиреоз.

ВСТУП. Пародонтит є шостим за поширеністю патологічним станом, який уражає 10,8 \%, або 743 млн, людей віком 15-99 років у всьому світі [1]. В Україні поширеність захворювань пародонта серед населення віком 35-44 роки становить від 92 до 98 \% [2]. Пародонтит виникає як наслідок імунної запальної реакції в результаті взаємодії між пародонтопатогенними бактеріями й організмом-господарем. Деструкцію тканин при захворюваннях пародонта вважають результатом зміни запально-імунної відповіді на мікробний наліт, і вона передбачає масове вивільнення фрагоцитів [3]. Накопичення активованих фрагоцитів супроводжується генерацією активних форм кисню, що призводить до оксидативного стресу [4, 5], який зумовлює серйозні (c) В. В. Щерба, І. Я. Криницька, М. М. Корда, 2019. ушкодження тканин пародонта [6]. Ключову роль у механізмі захисту структур ротової порожнини від бактеріальної інвазії відіграють клітини ясенного епітелію, які реалізують адаптивну імунну відповідь і вивільняють прозапальні цитокіни [7]. При цьому пародонтопатогенна мікрофрлора $€$ джерелом ендотоксинів, які, крім безпосередньої шкідливої дії на тканини пародонта, потрапляючи в кров, стимулюють підвищене продукування прозапальних цитокінів на системному рівні.

$€$ дані про те, що прогресивне руйнування кісткової тканини в пацієнтів 3 пародонтитом пов'язане з комбінацією цитокінів інтерлейкінів (IL) $1 \beta, 6$, фрактора некрозу пухлин- $\alpha$ (TNF- $\alpha)$ i простагландинів Е2. Ці цитокіни можуть активувати остеокластогенез і резорбцію кісткової тканини остеокластами. Посилення міграції 
макрофрагів під впливом цитокінів підвищує деструктивні процеси в пародонті [8]. Питання гормональної регуляції запальних реакцій у пародонті й особливості їх розвитку на тлі дисфункції щитоподібної залози залишаються недостатньо вивченими.

Мета дослідження - вивчити цитокіновий профріль сироватки крові та гомогенату пародонта в щурів з пародонтитом без супутньої патології і на тлі гіпер- та гіпотиреозу.

МЕТОДИ ДОСЛІДЖЕННЯ. Дослідження виконано на 48 безпородних статевозрілих білих щурах-самцях масою 180-200 г, яких утримували на стандартному раціоні віварію.

Піддослідних тварин було поділено на 4 групи. До 1-ї групи ввійшли контрольні тварини, яким вводили внутрішньошлунково $1 \%$ розчин крохмалю (n=12). Щури з моделлю пародонтиту становили 2-гу групу. В тканини ясен цих тварин протягом 2-х тижнів через день вводили по 40 мікролітрів (1 мг/мл) ліпополісахариду (ЛПС) E. coli ("Sigma-Aldrich", США) $(n=12)$ [9]. До 3-ї групи належали щури з пародонтитом на тлі гіпертиреозу. Для моделювання експериментальної гіперфункції щитоподібної залози тваринам упродовж 21-ї доби щоденно внутрішньошлунково вводили L-тироксин на $1 \%$ розчині крохмалю з розрахунку 10 мкг/добу на 100 г маси (n=12) [10]. Починаючи з 8-ї доби експерименту, в тканини ясен протягом 2-х тижнів вводили ЛПС. До 4-ї групи входили щури з пародонтитом на тлі гіпотиреозу. 3 метою моделювання експериментальної гіпофункції щитоподібної залози тваринам упродовж 21-ї доби щоденно внутрішньошлунково вводили мерказоліл на 1 \% розчині крохмалю з розрахунку 1 мг/добу на 100 г маси (n=12) [10]. Починаючи з 8-ї доби експерименту, в тканини ясен протягом 2-х тижнів вводили ЛПС. Евтаназію щурів здійснювали на 22-гу добу від початку досліду шляхом кровопускання за умов тіопентал-натрієвого наркозу.

Усі маніпуляції з експериментальними тваринами проводили з дотриманням правил відповідно до Європейської конвенції про захист хребетних тварин, що використовуються для дослідних та інших наукових цілей [11].

Для дослідження використовували сироватку крові та гомогенат пародонта, який виготовляли на трис/HCl/бусрері (pH 8,0) з розрахунку 100 мг тканини/мл [12]. Гомогенат центрифугували впродовж 30 хв при $1500 \mathrm{~g}$ і температурі $+4{ }^{\circ} \mathrm{C}$. Після центрисругування гомогенату досліджували надосадову рідину.

Для підтвердження станів гіпер- та гіпотиреозу в сироватці крові визначали вміст вільного тироксину $\left(\mathrm{BT}_{4}\right)$, вільного трийодтироніну $\left(\mathrm{BT}_{3}\right)$ та тиреотропного гормону (ТТГ) імуноферментним методом 3 використанням наборів фрірми "Вектор-Бест" (Росія).

Стан системного і місцевого запального процесу оцінювали за параметрами IL-1及, IL-4 та IL-10. Концентрацію цитокінів вивчали методом твердофазового імуноферментного аналізу 3 використанням наборів реагентів "RayBio" виробництва "RayBiotech" (США) відповідно до протоколу виробника на аналізаторі "Multiscan FC" (Фінляндія) та виражали у пг/мл.

Статистичну обробку цифрових даних здійснювали за допомогою програмного забезпечення Excel (Microsoft, США) і STATISTICA 6.0 (Statsoft, США) з використанням параметричних методів оцінки одержаних даних. Для всіх показників розраховували значення середньої арифметичної вибірки (М), її дисперсії і помилки середньої (m). Достовірність різниці значень між незалежними кількісними величинами визначали за допомогою критерію Стьюдента. Зміни вважали статистично достовірними при р<0,05.

РЕЗУЛЬТАТИ Й ОБГОВОРЕННЯ. ЦИТОКінИ $€$ важливими посередниками міжклітинних взаємодій, які регулюють імунну відповідь [13]. Відомо, що прозапальні цитокіни активують клітини епітелію, фрібробласти, макрофраги, які в результаті продукують медіатори запалення, ензими, що призводять до дегенерації міжклітинного матриксу і резорбції кісткової тканини [14]. Під час досліджень in vitro встановлено, що першим, але не єдиним, активатором в ясенній рідині, який бере участь в активації резорбції кісткової тканини, є цитокін IL-1. Відомо, що IL-1 в тканинах ясен активує і синтез інших цитокінів, наприклад IL-6, IL-8, TNF- $\alpha$ [15]. IL-1 є системою $з$ трьох

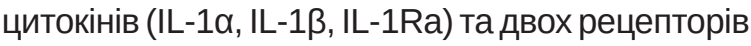
(R1 i R2). Домінуюча форма IL-1 - багатофункціональний IL-1 $\beta$, основними продуцентами якого є макрофраги і моноцити, а також лімфоцити, фрібробласти, ендотеліоцити [16]. Під час дослідження ми відмітили зростання концентрації IL-1 $\beta$ за умов пародонтиту без супутньої патології (табл.).

Так, у сироватці крові щурів із змодельованим пародонтитом цей показник зріс в 1,6 раза $(p<0,001)$ відносно контрольної групи. У тварин із змодельованим пародонтитом на тлі гіпертиреозу концентрація IL-1ß збільшилась у 2,5 раза $(p<0,001)$ щодо контрольної групи. Варто вказати, що в сироватці крові гіпертиреоїдних щурів вона на 51,5 \% достовірно перевищила величину даного показника за умов пародонтиту без супутньої патології та на 37,7 \% (p<0,001) - при пародонтиті на тлі гіпотиреозу. При цьому в сироватці крові тварин із змодельованим пародонти- 
Таблиця - Зміни цитокінового профрілю в щурів з пародонтитом без супутньої патології і на тлі гіпер- та гіпотиреозу $(\mathrm{M} \pm \mathrm{m}, \mathrm{n}=12)$

\begin{tabular}{|c|c|c|c|c|}
\hline \multirow[b]{2}{*}{ Показник, пг/мл } & \multicolumn{4}{|c|}{ Група тварин } \\
\hline & контрольна & пародонтит & $\begin{array}{l}\text { пародонтит на тлі } \\
\text { гіпертиреозу }\end{array}$ & $\begin{array}{l}\text { пародонтит на тлі } \\
\text { гіпотиреозу }\end{array}$ \\
\hline \multicolumn{5}{|c|}{ Сироватка крові } \\
\hline IL-1 $\beta$ & $8,31 \pm 0,62$ & $\begin{array}{c}13,57 \pm 0,78 \\
p_{1}<0,001\end{array}$ & $\begin{array}{c}20,56 \pm 1,06 \\
p_{1}<0,001 \\
p_{2}<0,001\end{array}$ & $\begin{array}{c}14,93 \pm 0,32 \\
p_{1}<0,001 \\
p_{3}>0,05 \\
p_{4}<0,001\end{array}$ \\
\hline IL-4 & $26,43 \pm 1,90$ & $\begin{array}{c}15,74 \pm 0,68 \\
p_{1}<0,001\end{array}$ & $\begin{array}{c}13,74 \pm 0,52 \\
p_{1}<0,001 \\
p_{2}<0,05\end{array}$ & $\begin{array}{c}22,93 \pm 0,90 \\
p_{1}>0,05 \\
p_{3}<0,001 \\
p_{4}<0,001\end{array}$ \\
\hline IL-10 & $16,53 \pm 0,71$ & $\begin{array}{c}8,05 \pm 0,65 \\
p_{1}<0,001\end{array}$ & $\begin{array}{l}4,98 \pm 0,20 \\
p_{1}<0,001 \\
p_{2}<0,001\end{array}$ & $\begin{array}{c}6,15 \pm 0,44 \\
p_{1}<0,001 \\
p_{3}<0,05 \\
p_{4}<0,05\end{array}$ \\
\hline \multicolumn{5}{|c|}{ Супернатант гомогенату пародонта } \\
\hline IL-1 $\beta$ & $4,55 \pm 0,36$ & $\begin{array}{c}9,07 \pm 0,65 \\
p_{1}<0,001\end{array}$ & $\begin{array}{c}13,41 \pm 0,60 \\
\mathrm{p}_{1}<0,001 \\
\mathrm{p}_{2}<0,001\end{array}$ & $\begin{array}{c}10,84 \pm 0,29 \\
p_{1}<0,001 \\
p_{3}<0,05 \\
p_{4}<0,01\end{array}$ \\
\hline IL-4 & $11,80 \pm 0,76$ & $\begin{array}{c}5,91 \pm 0,17 \\
p_{1}<0,001\end{array}$ & $\begin{array}{l}4,78 \pm 0,20 \\
p_{1}<0,001 \\
p_{2}<0,002\end{array}$ & $\begin{array}{c}6,81 \pm 0,26 \\
p_{1}<0,001 \\
p_{3}<0,02 \\
p_{4}<0,001\end{array}$ \\
\hline IL-10 & $7,21 \pm 0,30$ & $\begin{array}{c}3,11 \pm 0,15 \\
p_{1}<0,001\end{array}$ & $\begin{array}{c}1,89 \pm 0,15 \\
p_{1}<0,001 \\
p_{2}<0,001\end{array}$ & $\begin{array}{c}2,26 \pm 0,13 \\
p_{1}<0,001 \\
p_{3}<0,002 \\
p_{4}>0,05\end{array}$ \\
\hline
\end{tabular}

Примітки:

1. $p_{1}$ - достовірність відмінностей між контрольною і дослідними групами.

2. $p_{2}$ - достовірність відмінностей між групою щурів з пародонтитом і групою тварин з пародонтитом на тлі гіпертиреозу.

3. $p_{3}$ - достовірність відмінностей між групою щурів з пародонтитом і групою тварин з пародонтитом на тлі гіпотиреозу.

4. $p_{4}$ - достовірність відмінностей між групою щурів з пародонтитом на тлі гіпертиреозу і групою тварин 3 пародонтитом на тлі гіпотиреозу.

том на тлі гіпотиреозу концентрація IL-1ß також достовірно зрослав 1,8 разавідносно контрольної групи, проте достовірно не відрізнялася щодо групи щурів з пародонтитом без супутньої патології.

У супернатанті гомогенату пародонта тварин із змодельованим пародонтитом концентрація IL-1 $\beta$ підвищилась у 2,0 рази ( $<0,001)$, у щурів 3 пародонтитом на тлі гіпотиреозу - у 2,4 раза $(p<0,001)$ відносно контрольної групи. Найбільш виражено цей показник змінився у тварин з пародонтитом на тлі гіпертиреозу - зріс у 2,9 раза $(\mathrm{p}<0,001)$. Порівнюючи між собою отримані показники тварин різних дослідних груп, ми виявили достовірні відмінності концентрації IL-1ß: у тварин з пародонтитом без супутньої патології і на тлі гіпертиреозу - перевищення на 47,9 \% у гіпертиреоїдних щурів $(p<0,001) ;$ у тварин 3 пародонтитом без супутньої патології і на тлі гіпотиреозу - перевищення на 19,5 \% у гіпотиреоїдних щурів $(p<0,05) ;$ у тварин з пародонтитом на тлі гіпертиреозу та в щурів з пародонтитом на тлі гіпотиреозу - більші значення концентрації IL-1 $\beta$ у гіпертиреоїдних тварин (на 23,7 \%, p<0,01) (рис. 1).

Результати, які ми отримали, співзвучні 3 результатами інших дослідників, які встановили зростання вмісту IL-1 $\beta$ за умов пародонтиту в тканинах пародонта та ясенній рідині [17]. Підвищена секреція IL-1, мабуть, порушує механізми зворотного зв'язку, які обмежують запалення, що призводить до формування масивних кишень у ділянці зубоясенної борозни і деградації тканин пародонта [18].

Серед великої групи цитокінів IL-4 посідає особливе місце, оскільки проявляє як про-, так і протизапальну дію. Він не лише залучений у гуморальний імунітет, але також $€$ есенціальним регулятором імунної відповіді В- і Т-клітин та макросрагів [19]. Результати наших досліджень показали, що концентрація IL-4 у сироватці крові щурів із змодельованим пародонтитом знизилася на 40,4 \% $(p<0,001)$ відносно контрольної 


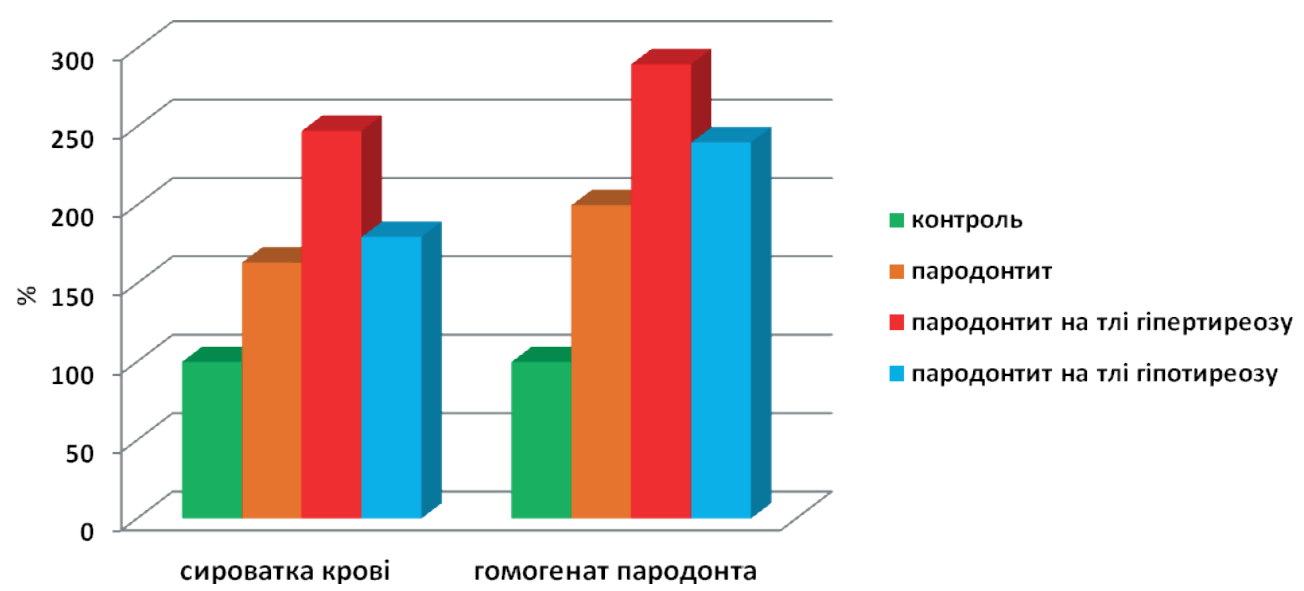

Рис. 1. Зміни концентрації інтерлейкіну $1 \beta$ за умов пародонтиту на тлі тиреоїдної диссрункції у відсотках.

групи. У тварин із змодельованим пародонтитом на тлі гіпертиреозу цей показник зменшився на 48,0 \% (р<0,001) щодо контрольної групи.

Варто вказати, що концентрація IL-4 у сироватці крові гіпертиреоїдних щурів на 12,7 \% була достовірно нижчою від даного показника за умов пародонтиту без супутньої патології та на 40,1 \% ( $<<0,001)$ - при пародонтиті на тлі гіпотиреозу. При цьому в сироватці крові тварин із змодельованим пародонтитом на тлі гіпотиреозу вона достовірно не відрізнялася відносно контрольної групи, перевищуючи величину даного показника на 45,7 \% $(p<0,05)$ щодо групи щурів з пародонтитом без супутньої патології (рис. 2).

У супернатанті гомогенату пародонта тварин із змодельованим пародонтитом концентрація IL-4 знизилася на 49,9 \% ( $p<0,001)$, у щурів 3 пародонтитом на тлі гіпотиреозу - на 42,3 \% ( $<<0,001)$ відносно контрольної групи. Найбільш виражено цей показник змінився у тварин з пародонтитом на тлі гіпертиреозу - зменшився на $59,5$ \% ( $p<0,001)$. Порівнюючи між собою отримані показники тварин різних дослідних груп, ми виявили достовірні відмінності концентрації IL-4: у тварин з пародонтитом без супутньої патології і на тлі гіпертиреозу - перевищення на 23,6 \% у щурів з пародонтитом без супутньої патології ( $<<0,001)$; у тварин з пародонтитом без супутньої патології і на тлі гіпотиреозу - перевищення на $15,2$ \% у гіпотиреоїдних щурів ( $<<0,02)$; у тварин з пародонтитом на тлі гіпертиреозу та в щурів 3 пародонтитом на тлі гіпотиреозу - більші значення концентрації IL-4 у гіпотиреоїдних тварин (на $42,5 \%, p<0,001$ ).

Інтерлейкін 10 належить до протизапальних цитокінів. Його продуцентами можуть бути моноцити, макрофраги, активовані Т-хелпери. Публікації про концентрацію IL-10 в тканинах пародонта не численні [20, 21].

У сироватці крові щурів із змодельованим пародонтитом цей показник знизився на 51,3 \% ( $<<0,001)$ відносно контрольної групи. У тварин із змодельованим пародонтитом на тлі гіпертиреозу концентрація IL-10 зменшилася на 69,9 \% ( $<<0,001)$ щодо контрольної групи. Варто вказати, що в сироватці крові гіпертиреоїдних щурів вона на 38,1 \% була достовірно нижчою від даного показника за умов пародонтиту без супутньої патології та на 19,0 \% $(p<0,05)$ - при пародонтиті на тлі гіпотиреозу. При цьому в си-

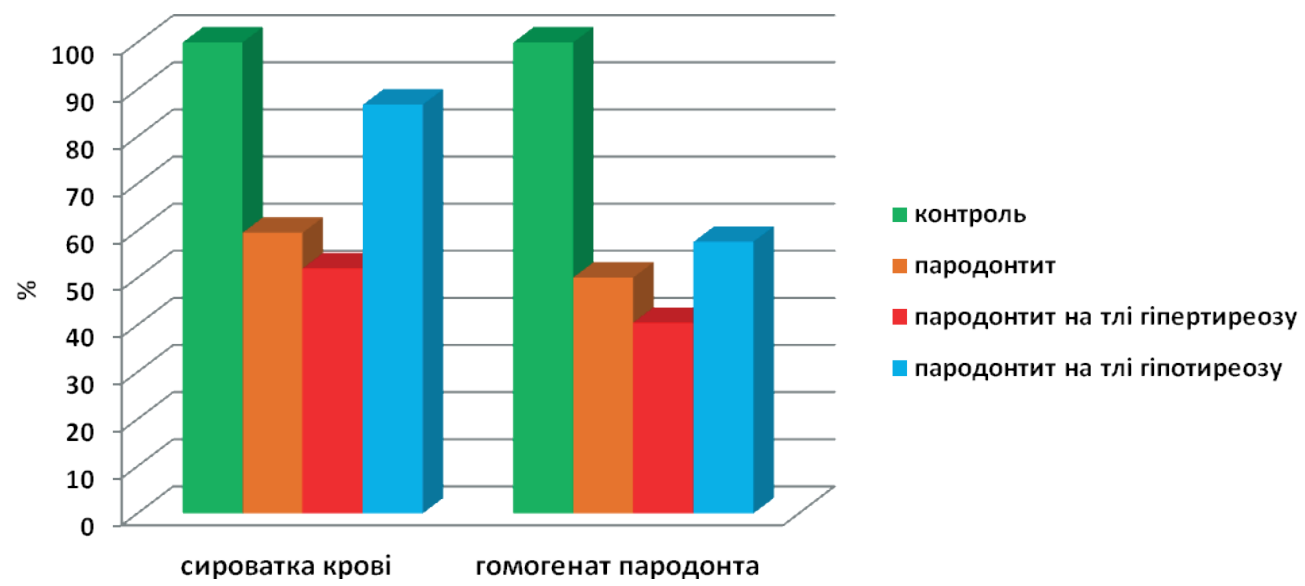

Рис. 2. Зміни концентрації інтерлейкіну 4 за умов пародонтиту на тлі тиреоїдної дисфункції у відсотках. 
роватці крові тварин із змодельованим пародонтитом на тлі гіпотиреозу концентрація IL-10 також достовірно зменшилася на 62,8 \% відносно контрольної групи та була на 23,6 \% $(p<0,05)$ нижчою щодо групи щурів з пародонтитом без супутньої патології (рис. 3).

У супернатанті гомогенату пародонта тварин із змодельованим пародонтитом концентрація IL-10 знизилася на 56,9 \% ( $<<0,001)$, у щурів 3 пародонтитом на тлі гіпотиреозу - на 68,7 \% ( $<0,001)$ відносно контрольної групи. Найбільш виражено цей показник змінився у тварин 3 пародонтитом на тлі гіпертиреозу - зменшився на
73,8 \% (p<0,001). Порівнюючи між собою отримані показники тварин різних дослідних груп, ми виявили достовірні відмінності концентрації IL-10: у тварин з пародонтитом без супутньої патології і на тлі гіпертиреозу - перевищення на 64,6 \% у щурів 3 пародонтитом без супутньої патології ( $<<0,001)$; у тварин з пародонтитом без супутньої патології і на тлі гіпотиреозу - перевищення на 37,6 \% у щурів з пародонтитом без супутньої патології ( $<<0,002)$. Зіставляючи результати, одержані у тварин з пародонтитом на тлі гіпертиреозу і пародонтитом на тлі гіпотиреозу, достовірних змін не встановили.

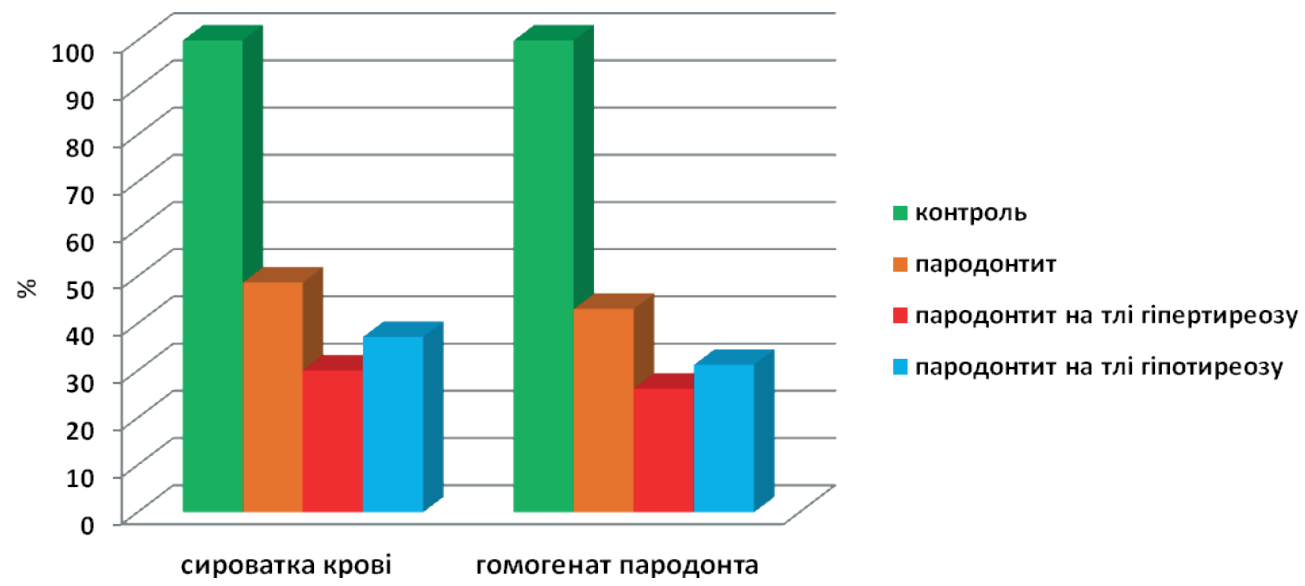

Рис. 3. Зміни концентрації інтерлейкіну 10 за умов пародонтиту на тлі тиреоїдної диссрункції у відсотках.

ВИСНОВКИ. Експериментальний пародонтит супроводжується вираженим підвищенням концентрації прозапальних цитокінів на тлі зниження концентрації протизапальних цитокінів як у гомогенаті пародонта, так і в сироватці крові, що свідчить про розвиток не лише локальних запальних реакцій, але й системних. Дисбаланс тиреоїдних гормонів впливає на перебіг запалення при експериментальному пародонтиті, особливо виражено - при гіпертиреозі.

\section{СПИСОК ЛІТЕРАТУРИ}

1. Global epidemiology of dental caries and severe periodontitis - a comprehensive review / J. E. Frencken, P. Sharma, L. Stenhouse [et al.] // J. Clin. Periodontol. 2017. - 44 (Suppl. 18). - P. S94-S105.

2. Оптимізація передопераційної підготовки в комплексному лікуванні хворих на генералізований пародонтит / М. Ю. Антоненко, Н.А.Зелінська, О. А. Значкова [та ін.] // Укр. журн. медицини, біології та спорту. - 2016. - № 2 (2). - С. 8-11.

3. Srivastava N. Point of care - a novel approach to periodontal diagnosis - a review / N. Srivastava, P. A. Nayak, S. Rana // J. Clin. Diagn. Res. - 2017. 11 (8). - P. ZE01-ZE06.

4. Криницька І. Я. Роль активних фрорм кисню у розвитку гепатопульмонального синдрому в експерименті / І. Я. Криницька // Здобутки клініч. і експерим. медицини. - 2012. - № 1. - С. 72-76.

5. Криницька І. Я. Рівень апоптично та некротично змінених моноцитів та альвеолярних макрофагів за умови експериментального гепатопульмонального синдрому / І. Я. Криницька // Світ медицини та біолоriï. - 2013. - № 2. - C. 46-49.

6. Oxidative stress parameters in saliva and its ass ociation with periodontal disease and types of bacteria / J. M. Almerich-Silla, J. M. Montiel-Company, S. Pastor [et al.] // Dis. Markers. - 2015. - Article ID 653537.

7. The influence of thyroid hormones on mitochond rial mechanisms of blood neutrophils' apoptosis in case of experimental periodontitis / V. Shcherba, O. Vydoinyk, L. Posolenyk, M. Korda // Archives of the Balkan Medical Union. - 2019. - 54, No. 1. - P. 64-71.

8. Duvina M. Biochemical markers as predictors of bone remodelling in dental disorders: a narrative description of literature // M. Duvina, L. Barbato // Clin. Cases Miner. Bone Metab. - 2012. - 9 (2). - P. 100-106.

9. Моисеева Е. Г. Метаболический гомеостаз и имунная реактивность организма в динамике воспаления в тканях пародонта (экспериментальное ис- 
следование) : автореф. дисс. на соискание учен. степени д-ра мед. наук / Е. Г. Моисеева. - М., 2008. $45 \mathrm{c}$.

10. Ратушненко В. О. Функціональна роль тіол-дисульсрідної системи при експериментальному гіпогіпертиреозі / В. О. Ратушненко // Одес. мед. журн. 2010. - № 2 (118). - C. 17-20.

11. European convention for the protection of verte brate animals used for experimental and other scientific purposes. - Council of Europe. Strasbourg. - 1986. No. 123. - Р. 52.

12. Авдєєв О. В. Ступінь активності фроссратаз при експериментальному пародонтиті та за його корекції / О. В. Авдєєв // Клініч. стоматологія. - 2013. - № 3-4. C. $13-17$.

13. Cytokines and chemokines: At the crossroads of cell signalling and inflammatory disease / M. D. Turner B. Nedjai, T. Hurst [et al.] // Biochim. Biophys. Acta. Mol. Cell Res. - 2014. - 1843, No. 11. - P. 2563-2582.

14. Rawlison A. Interleukin-1 and IL-1 receptor antagonist in gingival crevicular fluid / A. Rawlison, M. H. Datali, S. Rahman // Clin. Periodontol. - 2000. 27. - P. 738-743.

15. Александров Е. И. Микрофрлора и иммунологическая резистентность при кариесе зубов и заболеваниях пародонта на фоне сахарного диабета / Е. И. Александров // Медико-соціальні проблеми сім'ї. - 2014. - 19, № 1. - С. 109-114.

\section{REFERENCES}

1. Frencken, J.E., Sharma, P., Stenhouse, L., Green, D., Laverty, D. \& Dietrich, T. (2017). Global epidemiology of dental caries and severe periodontitis a comprehensive review. J. Clin. Periodontol., 44 (18), 94-105.

2. Antonenko, M.Yu., Zelinska, N.A., Znachkova, O.A., Melnychuk, T.A. \& Syroishko, M.V. (2016). Optymizatsiia peredoperatsiinoi pidhotovky $v$ kompleksnomu likuvanni khvorykh na heneralizovanyi parodontyt [Optimization of preoperative preparation in the complex treatment of patients with generalized periodontitis]. Ukrainskyi zhurnal medytsyny, biolohii ta sportu - Ukrainian Journal of Medicine, Biology and Sports, 2 (2), 8-11 [in Ukrainian].

3. Srivastava, N., Nayak, P.A. \& Rana S. (2017). Point of care - a novel approach to periodontal diagnosis - a review. J. Clin. Diagn. Res.,11 (8), ZE01-ZE06.

4. Krynytska, I.Ya. (2012). Rol aktyvnykh form kysniu u rozvytku hepatopulmonalnoho syndromu v eksperymenti [The role of reactive oxygen species in the development of hepatopulmonary syndrome in the experiment]. Zdobutky klinichnoi i eksperymentalnoi medytsyny Achievements of Clinical and Experimental Medicine, 1, 72-76 [in Ukrainian].

5. Krynytska, I.Ya. (2013). Riven apoptychno ta nekrotychno zminenykh monotsytiv ta alveoliarnykh makrofahivzaumovyeksperymentalnoho hepatopulmonalnoho syndromu [Level of apoptotic and necrotizing altered monocytes and alveolar macrophages under experimental
16. Зяблов Е. В. Закономерности изменений цитокинового статуса у больных фролликулярной и папиллярной формами рака щитовидной железы в динамике распространения неоплазии / Е. В. Зяблов, Н. П. Чеснокова, В. Ю. Барсуков // Фундаментальные исследования. - 2011. - № 5. - С. 62-67.

17. GCF IL-1beta profiles in periodontal disease / S. P. Engebretson, J. T. Grbic, R. Singer, I. B. Lamsret // J. Clin. Periodontol. - 2002. - 29 (1). - P. 48-53.

18. Царев В. Н. Аллельный полиморфизм генов ИЛ-1 $\alpha$ и ИЛ-1 $\beta$ у больных с хроническими воспалительными заболеваниями пародонта / В. Н. Царев, Е. Н. Николаева // Вестн. РАМН. - 2007. - 3. - С. 4347.

19. High interleukin-4 expression and interleukin-4 gene polymorphisms are associated with susceptibility to human paracoccidioidomycosis / M. S. Mendonça, T. S. Peraçolli, M. L. Silva-Vergara [et al.] // Jr. Mem. Inst. Oswaldo Cruz. - 2015. - 110, No. 6. - P. 781-785.

20. Over-expression of fork-head box $\mathrm{P} 3$ and its association with receptor activator of nuclear factor-kappa B ligand, interleukin (IL) - 17, IL - 10 and transforming growth factor-beta during the progression of chronic periodontitis / N. Dutzan, J. Gamonal, A. Silva [et al.] // J. Clin. Periodontal. - 2009. - 36. - P. 396-403.

21. Сабирова А. И. Цитокиновый статус у больных генерализованным пародонтитом и метаболическим синдромом / А. И. Сабирова // Вестн. КРСУ. - 2016. 16, № 7. - С. 102-105.

hepatopulmonary syndrome]. Svit medytsyny ta biolohii World of Medicine and Biology, 2, 46-49 [in Ukrainian].

6. Almerich-Silla, J.M., Montiel-Company, J.M., Pastor, S., Serrano, F., Puig-Silla, M. \& Dasi, F. (2015). Oxidative stress parameters in saliva and its associatio $\mathrm{n}$ with periodontal disease and types of bacteria. Dis. Markers. Article ID 653537.

7. Shcherba, V., Vydoinyk, O., Posolenyk, L. \& Korda, M. (2019). The influence of thyroid hormones on mitochondrial mechanisms of blood neutrophils' apopto sis in case of experimental periodontitis. Archives of the Balkan Medical Union, 54, 1, 64-71.

8. Duvina, M. \& Barbato, L. (2012). Biochemical markers as predictors of bone remodelling in dental disorders: a narrative description of literature. Clin. Cases Miner. Bone Metab., 9 (2), 100-106.

9. Moyseeva, E.G. (2008). Metabolicheskyy gomeostaz i imunnaya reaktivnost organizma v dinamyke vospaleniya $v$ tkanyakh parodonta [Metabolic homeostasis and immune reactivity of the organism in the dynamics of inflammation in periodontal tissues]. Extended abstract of Doctor's thesis. Sumy: SumSU [in Russian].

10. Ratushnenko, V.O. (2010). Funktsionalna rol tiol-dysulfidnoi systemy pry eksperymentalnomu hipo- i hipertyreozi [Functional role of thiol-disulphide system in experimental hypo- and hyperthyroidism]. Odeskyi medychnyi zhurnal - Odesa Medical Journal, 2 (118), 17-20 [in Ukrainian]. 
11. European convention for the protection of vertebrate animals used for experimental and other scientif ic purposes. (1986). Council of Europe. Strasbourg, 123, 52.

12. Avdieiev, O.V. (2013). Stupin aktyvnosti fosfataz pry eksperymentalnomu parodontyti ta za yoho korektsii [Stage of phosphatases activity during experimental parodontitis and after its correction]. Klinichna stomatolohiia - Clinical Stomatology, 3-4, 13-17 [in Ukrainian].

13. Turner, M.D., Nedjai, B. \& Hurst, T. (2014). Cytokines and chemokines: At the crossroads of cell signalling and inflammatory disease. Biochim. Biophys. Acta. Mol. Cell Res., 1843, 11, 2563-2582.

14. Rawlison, A., Datali, M.H. \& Rahman, S. (2000). Interleukin-1 and IL-1 receptor antagonist in gingival crevicular fluid. Clin. Periodontol., 27, 738-743.

15. Aleksandrov, E.I. (2014). Mikroflora i immunologicheskaya rezistentnost pri kariyese zubov i zabolevaniyakh parodonta na fone sakharnogo diabeta [Microflora and immunological resistance in case of dental caries and periodontal diseases on the background of diabetes mellitus]. Medyko-sotsialni problemy simi-Medico-social Problems of the Family, 19, 1, 109-114 [in Russian].

16. Ziablov, E.V., Chesnokova, N.P. \& Barsukov, V.Yu. (2011). Zakonomernosti izmeneniy tsitokinovogo statusa $\mathrm{u}$ bolnykh follikulyarnoy i papilliarnoy formami raka shchitovidnoy zhelezy $v$ dinamike rasprostraneniya neoplazii [Regularities of changes in cytokine status in patients with follicular and papillary forms of thyroid cancer in the dynamics of the spread of neoplasia]. Fundamentalnye issledovaniya - Basic Research, 5, 62-67 [in Russian].

17. Engebretson, S.P., Grbic, J.T., Singer, R. \& Lamsret, I.B. (2002). GCF IL-1beta profiles in periodontal disease. J. Clin. Periodontol., 29, 48-53.

18. Tsarev, V.N. \& Nikolayeva, E.N. (2007). Allelnyy polimorfizm genov IL-1 $\alpha$ i IL-1 13 u bolnykh s khronicheskimi vospalitelnymi zabolevaniyami parodonta [Allelic polymorphism of the genes IL-1 $\alpha$ and IL-1 in patients with chronic inflammatory periodontal diseases]. Vestnik RAMN - Bulletin of the Russian Academy of Medical Sciences, 3, 43-47 [in Russian].

19. Mendonça, M.S., Peraçolli, T.S., Silva-Vergara, M.L., Ribeiro, S.C., Oliveira, R.F., Mendes, R.P. \& Rodrigues, V.Jr. (2015). High interleukin-4 expression and interleukin-4 gene polymorphisms are associated $w$ ith susceptibility to human paracoccidioidomycosis. Jr. Mem. Inst. Oswaldo Cruz.,110, 6, 781-785.

20. Dutzan, N., Gamonal, J., Silva, A., Sanz, M. \& Vernal, R. (2009). Over-expression of fork-head box P3 and its association with receptor activator of nuclear factor-kappa B ligand, interleukin (IL) - 17, IL - 10 and transforming growth factor-beta during the progression of chronic periodontitis. J. Clin. Periodontal., 36, 396-403.

21. Sabirova, A.I. (2016). Tsitokinovyy status u bolnykh generalizovannym parodontitom i metabolicheskim sindromom [Cytokine status in patients with generalized periodontitis and metabolic syndrome]. Vestnik KRSU Bulletin of KRSU, 16, 7, 102-105 [in Russian].

\section{Резюме}

Вступление. В Украине распространенность заболеваний пародонта среди населения в возрасте 35-44 лет составляет от 92 до 98 \%. Вопрос гормональной регуляции воспалительных реакций в пародонте и особенности их развития на фроне дисфункции щитовидной железы остаются недостаточно изученными.

Цель исследования - изучить цитокиновый профиль сыворотки крови и гомогената пародонта у крыс с пародонтитом без сопутствующей патологии и на фроне гипер- и гипотиреоза.

Методы исследования. Исследование выполнено на белых крысах-самцах, у которых моделировали пародонтит, пародонтит на фроне гипертиреоза и пародонтит на фроне гипотиреоза. В сыворотке крови и супернатанте гомогената пародонта определяли содержание интерлейкинов (IL) $1 \beta, 4$ и 10 методом твердофразного иммуноферментного анализа с использованием наборов реагентов "RayBio" производства "RayBiotech" (США).

Результаты и обсуждение. Содержание провоспалительного IL-1 $\beta$ в сыворотке крови крыс с cмоделированным пародонтитом возрасло в 1,6 раза ( $p<0,001)$ относительно контрольной группы. У животных с смоделированным пародонтитом на фроне гипертиреоза этот показатель увеличился в 2,5 раза $(p<0,001)$ относительно контрольной группы. Следует указать, что концентрация IL-1 в в сыворотке крови гипертиреоидных крыс на 51,5 \% достоверно превысила величину данного показателя в условиях пародонтита без сопутствующей патологии и на 37,7 \% (p<0,001) - при пародонтите на фроне гипотиреоза. Содержание противовоспалительного IL-10 уменьшилось на 51,3\% (p<0,001) в сыворотке крови 
животных с смоделированным пародонтитом относительно контрольной группы. У крыс с смоделированным пародонтитом на фроне гипертиреоза данный показатель снизился на 69,9% (p<0,001) относительно контрольной группы. При этом содержание IL-10 в сыворотке крови гипертиреоидных животных на 38,1 \% было достоверно меньше данного показателя в условиях пародонтита без сопутствующей патологии и на 19,0% (р<0,05) - при пародонтите на фоне гипотиреоза.

Выводы. Экспериментальный пародонтит сопровождается выраженным повышением концентрации провоспалительных цитокинов на фроне снижения концентрации противовоспалительных цитокинов как в гомогенате пародонта, так и в сыворотке крови, что свидетельствует о развитии не только локальных воспалительных реакций, но и системных. Дисбаланс тиреоидных гормонов влияет на течение воспаления при экспериментальном пародонтите, особенно выражено - при гипертиреозе.

КЛЮЧЕВЫЕ СЛОВА: пародонтит; цитокины; гипотиреоз; гипертиреоз.

V. V. Shcherba, I. Ya. Krynytska, M. M. Korda I. HORBACHEVSKY TERNOPIL STATE MEDICAL UNIVERSITY

\title{
CHANGES IN THE CYTOKINE PROFILE IN RATS WITH PERIODONTITIS ON THE BACKGROUND OF HYPER- AND HYPOTHYROIDISM
}

\begin{abstract}
Introduction. In Ukraine, the prevalence of periodontal disease among the population aged 35-44 years ranges from 92 to $98 \%$. The question of the hormonal regulation of inflammatory reactions in the periodontium and the characteristics of their development against the background of thyroid dysfunction remain insufficiently studied.
\end{abstract}

The aim of the study - to investigate the cytokine profile of blood serum and periodontal homogenate in rats with periodontitis without comorbidities and against the background of hyper- and hypothyroidism.

Research Methods. The study was performed on white male rats, in which periodontitis, periodontitis on the background of hyperthyroidism and periodontitis on the background of hypothyroidism were modeled. The content of interleukins (IL) $1 \beta, 4$ and 10 in the blood serum and periodontal homogenate supernatant was determined by enzyme-linked immunosorbent assay using RayBio reagent kits manufactured by RayBiotech (USA).

Results and Discussion. The content of proinflammatory IL-1 $\beta$ in blood serum of rats with simulated periodontitis increased by 1.6 times $(p<0.001)$ relative to the control group. In rats with simulated periodontitis, against the background of hyperthyroidism, this index increased by 2.5 times $(p<0.001)$ relative to the control group. It should be noted that the concentration of IL-1 $\beta$ in the blood serum of hyperthyroidic rats by $51.5 \%$ probably exceeded the value of this indicator under condition of periodontitis without concomitant pathology and by $37.7 \%(p<0.001)-$ under the condition of periodontitis on the background of hypothyroidism. The content of anti-inflammatory IL-10 decreased by $51.3 \%(p<0.001)$ in blood serum of rats with simulated periodontium volume relative to the control group. In rats with simulated periodontitis on the background of hyperthyroidism, this indicator decreased by $69.9 \%(p<0.001)$ relative to the control group. At the same time, the content of IL-10 in the blood serum of hyperthyroidic rats by $38.1 \%$ was significantly lower than the given indicator in the case of periodontitis without concomitant pathology and by $19.0 \%(p<0.05)$ - under the condition of periodontitis against the background of hypothyroidism.

Conclusions. Experimental periodontitis is accompanied by a pronounced increase in the concentration of proinflammatory cytokines against the background of a decrease in the concentration of anti-inflammatory cytokines, both in the periodontal homogenate and in the blood serum, which indicates the development of not only local inflammatory reactions, but also systemic ones. An imbalance of thyroid hormones affects the course of inflammation in experimental periodontitis, especially in hyperthyroidism.

KEY WORDS: periodontitis; cytokines; hypothyroidism; hyperthyroidism.

Отримано 24.04.19

Адреса для листування: І. Я. Криницька, Тернопільський державний медичний університет імені І. Я. Горбачевського, майдан Волі, 1, Тернопіль, 46001, Україна, e-mail: krynytska@tdmu.edu.ua. 